\title{
Analisis Nilai-nilai Didaktis Novel Si Anak Badai Karya Tere Liye: Tinjauan Sosiologi Sastra
}

\author{
Indriani Suharyan \\ Program Studi Pendidikan Bahasa Indonesia \\ Fakultas Keguruan dan Ilmu Pendidikan \\ Universitas Siliwangi \\ indrianisuharyan@gmail.com
}

\begin{abstract}
This research aims to describe the didactics values, including moral values, social values, cultural values, and religion values contained in Si Anak Badai by Tere Liye. The method used in this research is qualitative descriptive method. Qualitative descriptive method is a method that refers to describing and analyzing a study. The data collection techniques used in this research is simak-catat and documentation techniques. Based on the research, the moral values found include: helping parents, loving others, apologizing for mistakes, saying thank you, being trustworthy, and nothing surrender. The social values found include: responsibility, helping for others, mutual cooperation, social care, and deliberation. The cultural values found include: raising hands as a request for permission to ask or answer and respecting guests. And the religion values found include: salat as an obligation to God, reciting Qur'an as an amalan, and praying before and after doing activities.
\end{abstract}

Keywords: didactics values; novel; qualitative descriptive

\begin{abstract}
Abstrak: Penelitian ini bertujuan untuk mendeskripsikan nilai-nilai didaktis, mencakup nilai moral, sosial, budaya, dan agama yang terdapat dalam novel Si Anak Badai karya Tere Liye. Metode yang digunakan dalam penelitian ini ialah metode deskriptif kualitatif. Deskriptif kualitatif merupakan metode yang mengacu pada kegiatan menggambarkan atau menganalisis suatu penelitian. Teknik pengumpulan data yang digunakan dalam penelitian ini ialah teknik simak-catat dan teknik dokumentasi. Berdasarkan penelitian ini, ditemukan nilai moral, di antaranya: membantu orangtua, sikap kasih sayang kepada sesama, meminta maaf saat melakukan kesalahan, mengucapkan terima kasih, bersikap amanah, dan pantang menyerah. Sementara nilai sosial yang ditemukan, di antaranya: tanggung jawab, tolong menolong, gotong royong, kepedulian terhadap sesama, dan musyarah. Kemudian nilai budaya yang ditemukan, di antaranya: mengangkat tangan sebagai permintaan izin bertanya atau menjawab, serta menghormati tamu. Lalu nilai agama yang ditemukan, di antaranya: mendirikan shalat sebagai kewajiban terhadap Tuhan, mengaji sebagai amalan, serta berdoa sebelum dan setelah melakukan kegiatan.
\end{abstract}

Kata Kunci: nilai-nilai didaktis; novel; deskriptif kualitatif 


\section{Pendahuluan}

Karya sastra mengandung amanat yang dapat memberikan motivasi dan refleksi bagi pembacanya. Motivasi dan refleksi tersebut disampaikan melalui nilai-nilai pendidikan; mencakup nilai agama, sosial, budaya, maupun moral. Sumaryanto (2019: 1-2) mengemukakan bahwa karya sastra merupakan penjelmaan kehidupan hasil pengamatan sastrawan atas kehidupan sekitarnya. Melalui karyanya, sastrawan berusaha mengungkapkan makna hidup dan kehidupan sesuai yang ditangkap oleh mata batinnya. Seorang pemikir Romawi, Horatius (dalam Haerudin, 2012) mengemukakan istilah dulce et utile, dengan tulisannya berjudul Art Poetice. Artinya, karya sastra sebagai bahan bacaan mempunyai fungsi ganda, yakni menghibur dan sekaligus bermanfaat bagi pembacanya. Secara umum, karya sastra menyajikan para pembacanya rentetan kehidupan manusia, termasuk memunculkan perasaan, sifat, serta sikap yang lazimnya melekat dalam diri manusia itu, seperti perasaan bahagia, sedih, gembira, putus asa, apatis, ikhlas; sifat serakah, percaya diri, ambisius, optimis, pesimis; sikap jujur, bertanggung jawab, rela berkorban, dll.

Novel merupakan salah satu jenis karya sastra. Sebagai karya fiksi, novel tentu memuat pesan dari pengarangnya. Menurut Soemardjo dan Saini (dalam Raharjo dan Wiyanto, 2017: 5) novel adalah cerita berbentuk prosa dalam ukuran yang luas. Ukuran luas yang dimaksud dalam pernyataan tersebut berupa unsur yang kompleks dalam novel, meliputi plot, tokoh, konflik, tema, suasana, latar, dan lain-lain. Sementara, menurut Raharjo dan Wiyanto (2017: 5) novel adalah sebuah karya fiksi yang memaparkan ide, gagasan, dan khayalan dari pengarang. Diksi yang berbeda diungkapkan Sumaryanto (2019: 39) dalam mendefinisikan novel, menurutnya novel adalah cerita prosa yang mengisahkan suatu kejadian luar biasa sehingga menciptakan suatu konflik yang mengakibatkan adanya perubahan nasib pelakunya. Berdasarkan ketiga pendapat tersebut, maka novel dapat diartikan sebagai sebuah karya sastra berbentuk prosa yang bersumber dari ide, gagasan, serta khayalan pengarang, yang menceritakan suatu kejadian luar biasa sehingga melahirkan konflik yang mengakibatkan adanya perubahan nasib pelakunya serta mengandung unsur yang kompleks seperti plot, tokoh, konflik, tema, suasana, latar, dan lainnya.

Penganalisisan novel berguna untuk mengeruk sekaligus menjabarkan nilai-nilai positif yang terkandung dalam karya sastra. Oleh karena itu, penelitian ini bertujuan untuk mendeskripsikan nilai-nilai didaktis, mencakup nilai moral, sosial, budaya, dan agama yang terdapat dalam novel Si Anak Badai karya Tere Liye. Ibung (2008: 3) berpendapat bahwa moral adalah suatu keyakinan tentang benar salah, baik dan buruk, yang sesuai dengan kesepakatan sosial, yang mendasari tindakan atau pemikiran. Nopitasari (2020: 10) mengemukakan bahwa nilai sosial merupakan sikap dan perasaan yang diterima secara luas oleh masyarakat dan merupakan dasar untuk menetapkan apa yang benar dan apa yang utama. Sementara, nilai budaya merupakan nilai-nilai yang telah disepakati dan tertanam dalam suatu masyarakat yang kemudian mengakar pada suatu kebiasaan ataupun kepercayaan (Nopitasari, 2020: 17). Lalu, nilai agama merupakan nilai yang tidak hanya terbatas pada ibadah, tetapi juga segala macam hal yang berkaitan dengan ibadah yang 
dijalani (Nopitasari, 2020: 29).

Pendekatan utama penelitian ini ialah sosiologi sastra. Sosiologi sastra digunakan untuk menganalisis nilai-nilai didaktis yang terdapat dalam novel. Novel dikatakan sebagai refleksi dari struktur sosial. Artinya, di dalam novel terkandung potret masyarakat secara umum ditinjau dari sudut lingkungan tertentu yang terbatas. Penelitian sosiologi sastra memunculkan perspektif bahwa karya sastra merupakan ekspresi dan bagian dari masyarakat, dengan demikian karya sastra memiliki nilai dalam masyarakat tersebut. Menurut Suwardi (2011), sosiologi sastra adalah ilmu yang memanfaatkan faktor sosial sebagai pembangun sastra.

Berdasarkan penjabaran di atas, penulis akan mengkaji lebih mendalam tentang nilai-nilai didaktis yang terdapat dalam novel Si Anak Badai karya Tere Liye dengan memanfaatkan tinjauan sosiologi sastra. Si Anak Badai merupakan novel keenam dari Serial Anak Nusantara yang merepresentasikan kehidupan anak-anak di kampung nelayan bernama Muara Manowa. Novel ini bercerita tentang anak laki-laki bernama Zaenal dan ketiga temannya yang terus berupaya mempertahankan kampung halaman mereka (Muara Manowa) dari gusuran pemerintah akibat rencana pembangunan pelabuhan. Di saat warga Kampung Manowa hanya bisa pasrah menghadapi fakta bahwa tempat tinggal mereka sebentar lagi akan dirobohkan, lain halnya dengan Za dan kawan-kawan yang justru berusaha mencari cara untuk menggagalkan rencana pembangunan tersebut. Pada akhirnya, kekompakkan dan semangat mereka mampu membawa bukti tak terbantahkan yang dapat menyelamatkan Kampung Manowa dari penggusuran. "Si Anak Badai" merupakan julukan geng Za dan kawan-kawannya, hal tersebut karena kehidupan mereka tidak terlepas dari lautan dengan segala macam tantangan dan rintangan.

Cerita mengenai anak bangsa yang hidup dalam keceriaan dan kesederhanaan tentunya menampilkan banyak amanat serta pesan bijak mengenai kehidupan yang hendak disampaikan penulis kepada pembaca. Maka dari itu, dalam penelitian ini penulis berfokus menganalisis nilai-nilai pendidikan yang terkandung dalam novel Si Anak Badai berdasarkan data empiris yang ditemukan. Data tersebut dapat berupa dialog antar tokoh maupun narasi.

\section{Metode Penelitian}

Penelitian ini termasuk ke dalam penelitian kualitatif dengan menggunakan metode deskriptif. Deskriptif kualitatif merupakan metode yang mengacu pada kegiatan menggambarkan atau menganalisis suatu penelitian. Oleh karena itu, penelitian ini akan menjabarkan secara deskriptif mengenai informasi maupun data penelitian yang telah dikumpulkan. Pendekatan sastra yang digunakan dalam penelitian ini ialah pendekatan sosiologi sastra. Selain itu, penelitian ini juga menggunakan desain metode analisis isi (content analysis) untuk mengetahui amanat dan nilai-nilai yang terdapat dalam sumber data 
penelitian. Analisis isi adalah metode ilmiah untuk mempelajari dan menarik kesimpulan atas suatu fenomena dengan memanfaatkan dokumen/teks (Eriyanto, 2011: 10). Sumber data penelitian adalah novel Si Anak Badai karya Tere Liye. Sumber data ini menguraikan langkah-langkah penelitian, dari mulai pengambilan data, analisis, dan konklusi. Data yang disimpulkan merupakan data nilai-nilai didaktis, mencakup nilai moral, nilai sosial, nilai budaya, dan nilai agama yang terdapat dalam novel.

Teknik pengumpulan data yang digunakan dalam penelitian ini ialah teknik simakcatat dan teknik dokumentasi. Dalam praktiknya, teknik catat adalah teknik lanjutan dari teknik simak. Mahsun (dalam Rahayu, 2012) menyebutkan bahwa teknik catat merupakan metode mencatat beberapa bentuk yang relevan bagi penelitian secara tertulis. Rosidi (dalam Putro dkk., 2020) mengemukakan bahwa teknik dokumentasi adalah cara pengumpulan data dengan melihat dan menyelidiki data-data tertulis yang ada di buku, majalah, dokumen, surat, dll. Langkah-langkah pengumpulan data antara lain mengidentifikasi narasi maupun dialog yang mengacu pada aspek nilai-nilai didaktis dalam novel Si Anak Badai. Selanjutnya, hasil identifikasi ditranskripsikan atau dicatat dalam lembar kerja. Data yang telah dikumpulkan kemudian dianalisis, sebelum akhirnya ditarik suatu kesimpulan.

\section{Hasil dan Pembahasan}

Data yang diperoleh dari analisis yang telah dilakukan ialah sebagai berikut.

\section{Nilai Moral}

\section{Membantu Orang Tua}

Kutipan yang menunjukkan adanya sikap membantu orang tua, yaitu:

Aku mendapati Fatah menunggu berdiri di luar rumah-di atas jalan papan ulin. Tangannya memegang buku dan meteran kain, di telinga terselip pensil. Urusan mengukur pakaian seperti ini sudah beberapa kali kami lakukan. Sudah bisa membantu Mamak mengukur baju atau celana, jadi paham caranya.

Sekarang kami berjalan menuju rumah Pak Kapten. Meniti jalan papan ulin. Rumahnya di hulu kampung, dekat dengan jembatan ke masjid. Pak Kapten tinggal bersama istrinya. Mereka punya anak satu-satunya, Paman Deham-sudah menikah, sudah punya rumah sendiri pula. Rahma-anak sulung Paman Deham, sekelas denganku. (Bagian 2)

Kutipan tersebut dilontarkan oleh tokoh Za. Dalam kutipan tersebut, terlihat bahwa tokoh Za dan Fatah menunjukkan akhlak terpuji berupa membantu Mamak mengukurkan pakaian milik Kakek (Pak Kapten). Tindakan tersebut bukanlah untuk pertama atau kedua kalinya, karena mereka kerap kali membantu tokoh Mamak mengukur baju dan celana milik warga Kampung Manowa yang memesan jahitan. Membantu orang tua merupakan salah satu bentuk sikap khidmat seorang anak terhadap sosok yang telah merawat, membesarkan, dan mendidiknya. Tokoh $\mathrm{Za}$ dan Fatah telah tumbuh dalam lingkungan keluarga yang 
membentuk kesadaran mereka untuk senantiasa berbakti dan menghormati Mamak Bapak.

Berdasarkan kutipan tersebut, maka bagi tokoh Za dan Fatah, membantu orang tua adalah suatu kewajiban yang didasari pada kedudukan sebagai seorang anak, tuntutan hidup (berupa tuntutan ekonomi), serta kebiasaan dan pengajaran sejak kecil.

\section{Sikap Kasih Sayang kepada Sesama}

Kutipan yang menunjukkan adanya sikap kasih sayang kepada sesama, yaitu:

"Nanti, kalau jahitan ini selesai, Thiyah, Fatah dan Zaenal akan Mamak bawa ke pasar terapung, Bang. Mamak akan bebaskan mereka beli makanan apa saja. Biar mereka tahu kalau Mamak sungguh sayang dengan mereka bertiga."

Di ruang tengah, aku tersenyum dengan mata berkaca-kaca, tak tertahankan. Aku menangis. Aku baru tahu betapa sayangnya Mamak kepada kami. (Bagian 11)

Dalam kutipan tersebut, terlihat bahwa tokoh Mamak menunjukkan rasa kasih sayang kepada anak-anaknya-Thiyah, Fatah, dan Zaenal, dengan berencana untuk mengajak mereka berjalan-jalan ke pasar terapung. Hal tersebut ia lontarkan kepada tokoh Bapak. Sikap kasih sayang kepada sesama dalam novel ini tidak hanya dijewantahkan dalam bentuk kasih sayang orangtua kepada anak, tetapi juga anak kepada orang tua, kepada sesama teman, kepada sesama tetangga, maupun kepada sesama manusia. Berikut salah satu kutipannya:

"Tapi Pak, kan yang lebih penting membuat masakan buat kami, bukan membuat enam belas baju kurang itu.” Fatah masih protes.

"Itu juga sama pentingnya, Fat. Mamak kalian tidak bisa ikut latihan rebana, tapi dia tetap mau terlibat dalam grup itu, dengan menjahitkan gratis baju kurungnya. Ayo, habiskan makanan kalian. Bayangkan semua perjuangan Mamak, pasti akan terasa lezat." (Bagian 11)

Dalam kutipan tersebut, terlihat bahwa tokoh Bapak tengah berusaha menenangkan Fatah (anaknya) yang merengek karena kesibukan Mamak berimbas pada hasil masakannya yang tidak lezat. Tokoh Bapak menegaskan bahwa hal tersebut wajar karena tokoh Mamak memang sedang sibuk-sibuknya menjahit baju kurung milik ibu-ibu grup rebana. Adapun alasan pembuatan baju kurung itu ialah untuk digunakan ibu-ibu pada saat penampilan qosidah dalam rangka menyambut kunjungan gubernur ke Kampung Manowa. Sikap kasih sayang tercermin dari fakta yang menyebutkan bahwa tokoh Mamak menawarkan bantuan untuk membuatkan 16 baju kurung dengan sukarela, tanpa meminta sedikit pun bayaran.

Dari kenyataan itu, dapat kita ketahui pula bahwa masyarakat Kampung Manowa telah hidup berdampingan dengan rukun dan damai selama bertahun-tahun. Kerukunan dan kedamaian seperti inilah yang dapat melahirkan sikap kasih sayang kepada sesamanya. 


\section{Meminta Maaf saat Melakukan Kesalahan}

Kutipan yang menunjukkan adanya sikap meminta maaf saat melakukan kesalahan, yaitu:

"Mamak minta maaf, Fat. Mamak tidak sengaja. Harus berapa kali Mamak bilang hingga kau mau memaafkan.” Mamak menatap Fatah. (Bagian 6)

Dalam kutipan tersebut, terlihat bahwa tokoh Mamak meminta maaf kepada Fatah atas kesalahan yang diperbuatnya. Adapun kesalahan itu berupa kekeliruan membungkus baju hasil jahitan milik Kakek dan Wak Sidiq perempuan. Meminta maaf memang sepatutnya dilakukan seseorang ketika berbuat salah kepada orang lain, meskipun hanya karena persoalan yang kecil. Terdapat fakta yang perlu digarisbawahi dan dipelajari dalam kutipan di atas, fakta bahwa yang meminta maaf adalah seorang ibu kepada anak. Mengapa perlu digarisbawahi? Karena hal tersebut jarang terjadi. Umumnya, seorang ibu enggan meminta maaf kepada anaknya meskipun ia menyadari telah berbuat salah, hal itu terjadi karena stigma yang berkembang di masyarakat yang menyebutkan bahwa orang tua adalah superior.

\section{Mengucapkan Terima Kasih}

Kutipan yang menunjukkan adanya tindakan mengucapkan terima kasih, yaitu:

Tidak sempat aku memperhatikan Malim dan Ode menggodaku, ada urusan yang lebih penting, karena Rahma terlihat nyaris jatuh ke sungai saat lompat ke atas perahu. Aku reflek meraih tangannya, membantunya menjaga keseimbangan.

“Terima kasih, Za.” Wajah Rahma sedikit pias. (Bagian 15)

Dalam kutipan tersebut, terlihat bahwa tokoh Rahma berterima kasih kepada Za karena telah membantunya menjaga keseimbangan saat lompat ke atas perahu. Terima kasih diucapkan oleh seseorang kepada orang lain yang telah memberikan bantuan. Sama seperti meminta maaf, mengucapkan terima kasih juga sepatutnya dilakukan seseorang kepada orang lain, sekalipun hanya karena pertolongan yang kecil.

\section{Bersikap Amanah}

Kutipan yang menunjukkan adanya sikap amanah, yaitu:

"Apa pesan yang kalian bawa dari Wak perempuan?"

Aku menggamit Fatah, mengajaknya berdiri dekat dengan Wak Sidiq.

“Wak perempuan minta dibelikan beras.” (Bagian 4)

Dalam kutipan tersebut, terlihat bahwa tokoh Za dan Fatah tengah menyampaikan amanah kepada Wak Sidiq. Adapun amanah yang mereka dapatkan ialah Wak Sidiq 
perempuan meminta Wak Sidiq laki-laki untuk membelikan beras. Amanah tersebut pun berhasil Za dan Fatah sampaikan dengan baik dan jujur.

\section{Pantang Menyerah}

Kutipan yang menunjukkan adanya sikap pantang menyerah, yaitu:

“Oi! Oi!” Awang mengangkat bahuku, "Kita punya bukti hebat sekarang."

"Kita harus segera ke rumah Wak Sidiq, rekaman ini harus dibawa ke ibu kota secepat mungkin."

CTAR!

BUM!

Petir sekali menyambar, disusul dentum geledek.

Badai kembali turun membungkus kampung kami. Tapi kali ini, aku mendongak, menatap jutaan tetes air hujan dengan riang. Inilah kami, Si Anak Badai. Tekad kami sebesar badai. Kami Tidak pantang menyerah. (Bagian 25)

Dalam kutipan tersebut, terlihat bahwa tokoh Aku (Za) memiliki tekad yang kuat dalam menjaga sekaligus membela kebenaran. Narasi tersebut ditampilkan dalam novel ketika tokoh Za dan kawan-kawannya-Awang, Ode, dan Malim-berhasil menjalankan rencana mereka menggagalkan pembangunan pelabuhan dengan menyusup ke kapal yacht untuk mendapatkan bukti pendukung. Awalnya, rencananya mereka memang tidak membuahkan hasil, tetapi karena sikap pantang menyerah yang mereka miliki, akhirnya rencana kedua sukses dijalankan dengan hasil yang sesuai dan memuaskan. Sebelum menjalankan rencana kedua, mereka juga senantiasa belajar dari kesalahan pada saat menjalankan rencana pertama, yakni dengan menyusun strategi yang lebih baik, melakukan pengamatan, serta memikirkan kemungkinan-kemungkinan dan peluang-peluang yang terjadi. Sikap pantang menyerah merupakan nilai karakter yang dapat membentuk kepribadian seseorang menjadi berani dan tangguh.

\section{Nilai Sosial}

\section{Tanggung Jawab}

Kutipan yang menunjukkan adanya sikap bertanggung jawab, yaitu:

"Mamak menyuruh kita bertanggung jawab, Fat. Kakak tidak mau pulang sebelum urusan ini selesai. Bisa panjang. Kita bisa dihukum tidur di teras rumah. Kalau kau tidak mau ikut, biar aku saja." Tanpa menunggu reaksi Fatah, aku mengulurkan tangan, meminta buku tulis dan pensil yang ada padanya. (Bagian 4)

Dalam kutipan tersebut, terlihat bahwa tokoh Za menyadari akan kesalahannya dan 
mau bertanggung jawab. Adapun kesalahan yang Za lakukan ialah telah keliru mengukur ukuran baju Wak Sidiq, kemudian ia pun bertanggung jawab untuk menebus kesalahan itu dengan mendatangi Wak Sidiq dan mengukurnya kembali. Hal yang sama dilakukan pula oleh adiknya Za, yakni Fatah. Dari kutipan tersebut, kita ketahui bahwa tokoh Za mampu berpikir secara matang dan bijak, meskipun usianya terbilang sangat muda (masih duduk di bangku kelas 6 sekolah dasar). Ia segera bertanggung jawab setelah menyadari kesalahannya. Tanggung jawab itu pun dilakukannya dengan sungguh-sungguh. Sikap tanggung jawab dan karakter yang dimiliki Za boleh terbentuk karena kedudukannya sebagai seorang kakak yang memiliki dua adik, kedudukannya sebagai anak pertama. Ia memiliki pengalaman yang lebih banyak. Ia memiliki kesadaran bahwa ia harus menjadi contoh yang baik bagi kedua adiknya.

\section{Tolong Menolong}

Kutipan yang menunjukkan adanya sikap tolong menolong, yaitu:

Tapi entah apa yang dipikirkannya, mungkin karena kasihan melihat Mutia yang hendak menangis lagi, atau karena barusan dibilang jahat, Awang mendadak menawarkan membantu, "Baiklah kalau begitu. Kau tenang saja, Tia. Sebelum lonceng tanda istirahat selesai, aku akan membawa kembali pena kesayangan kau itu." (Bagian 3)

Dalam kutipan tersebut, terlihat bahwa tokoh Awang menawarkan bantuan kepada Mutia untuk mengambil pena kesayangannya yang terjatuh di muara sungai di bawah bangunan sekolah. Sebagai teman sekaligus kakak kelas, Awang bersedia menolong Mutia dengan ikhlas.

\section{Gotong Royong}

Kutipan yang menunjukkan adanya rasa gotong royong, yaitu:

Sore ini kami membuat tangga darurat. Bang Kopli dan pemuda kampung sudah mengambil batang bamboo dan beberapa potong kayu di seberang sungai. Akan ada dua tangga yang dibuat. Satu di sisi masjid, satunya lagi di sisi jalan papan. Wak Albet berikut nelayang stelah menyanggupi menyeberangkan jamaah dari jalan papan ke masjid dan sebaliknya dengan perahu. (Bagian 8) 
Dalam kutipan tersebut, terlihat bahwa warga Kampung Manowa tengah melakukan gotong royong untuk menyiasati akses jalan ke masjid yang terputus. Terdapat dua bentuk gotong royong yang mereka lakukan, 1) gotong royong membuat tangga darurat, dan 2) gotong royong menyeberangkan jamaah dari jalan papan ulin ke masjid ataupun sebaliknya dengan perahu.

\section{Kepedulian terhadap Sesama}

Kutipan yang menunjukkan adanya rasa peduli terhadap sesama, yaitu:

"Kenapa kalian datang ke sini?" Suara Malim tidak ramah, dia tahu kami hanya akan mengganggunya saja.

Siang ini aku, Awang, dan Ode datang bertiga. Malim terlihat tidur-tiduran di atas bale, menunggu kapal melintas.

“Kalian hanya merecokiku dengan memintaku sekolah, kan?” Malim melotot. (Bagian 16)

Dalam kutipan tersebut, terlihat bahwa tokoh Aku (Za), Awang, dan Ode memiliki kepedulian kepada kawannya, bernama Malim. Kepedulian itu dicurahkan dalam bentuk ajakan untuk kembali ke sekolah, karena pada saat itu diceritakan bahwa Malim tidak ingin lagi bersekolah, melainkan lebih memilih untuk mencari uang dengan menunggu kapal. Tindakan mendatangi Malim untuk mengajaknya kembali ke sekolah bukan sekali dilakukan oleh Za dan kawan-kawannya, melainkan berkali-kali. Sebab Malim tak lantas menyanggupi permintaan mereka, menolak satu sampai tiga kali. Namun, hal tersebut tidak menyurutkan semangat $\mathrm{Za}$ dan kawan-kawannya untuk terus membujuk Malim hingga bersedia. Pada akhirnya, kepedulian Za dan kawan-kawannya mampu meluluhkan hati Malim dan membuatnya mau kembali bersekolah.

\section{Musyawarah}

Kutipan yang menunjukkan adanya sikap bermusyawarah, yaitu:

Di rumah Wak Sidiq, Bang Kopli yang melapor. Wak Sidiq memerintahkan pemuda yang dituduh maling didudukkan di ruang depan. Kak Ros dan kami bertiga diminta masuk juga. Malim yang tidak disebut namanya, penuh percaya diri ikut masuk. Sementara anak-anak lain menonton dari teras. (Bagian 14)

Dalam kutipan tersebut, terlihat bahwa tokoh Wak Sidiq dan beberapa pihak yang bersangkutan tengah melakukan musyawarah untuk menyelesaikan masalah. Adapun persoalan yang mereka selesaikan ialah mengenai pencurian yang diduga terjadi pada Kak Ros. Dalam novel diceritakan bahwa tas berisi uang milik tokoh Kak Ros telah hilang, dan diduga dicuri oleh pencuri bernama Unan. Namun, dugaan tersebut ternyata salah setelah dilakukan penyelidikan dan perembukan. Faktanya, tas milik Kak Ros tertinggal di perahu saat membeli sayur rebung di pasar terapung.

\section{Nilai Budaya}

\section{Mengangkat Tangan sebagai Permintaan Izin Bertanya/Menjawab}

Kutipan yang menunjukkan adanya tindakan mengangkat tangan sebagai permintaan izin bertanya/menjawab, yaitu: 
"Nah, terkait kapal ini, mengapa Allah memerintahkan Nabi Nuh membuat kapal yang besar, bukan pesawat yang besar, atau gedung yang tinggi, atau balon terbang raksasa?" Guru Rudi memandangi kami.

Kami saling tatap. Apa maksud Guru Rudi?

"Guru," Thiyah mengangkat tangannya-seperti biasa dia selalu semangat menjawab, "Sebab saat itu manusia baru bisa membuat kapal. Belum bisa membuat pesawat terbang." (Bagian 5)

Dalam kutipan tersebut, terlihat bahwa tokoh Thiyah mengangkat tangannya sebagai permintaan izin menjawab pertanyaan yang diajukan oleh Guru Rudi setelah kegiatan mengaji. Budaya mengangkat tangan berlaku di Kampung Manowa saat ingin bertanya/menjawab, hal ini sebagai bentuk kesopanan terhadap yang lebih tua/berilmu. Dalam kehidupan nyata, budaya ini banyak dilakukan di berbagai macam tempat di belahan dunia, dan Kampung Manowa sebagai latar tempat novel ini pun memiliki tradisi yang sama.

\section{Menghormati Tamu}

Kutipan yang menunjukkan adanya sikap menghormati tamu, yaitu:

... Kami bertiga memandang tak berkedip. Bapak itu berjalan ke dalam tenda ditemani seorang berbaju pegawai, dengan emblem melekat di bajunya. Kupikir itulah Camat Tiong. Dari mobil kedua keluar lima orang pemuda seumuran Bang Kopli. Semuanya memakai baju safari hitam, pandangan mereka tampak selalu waspada.

"Selamat datang Bapak dari provinsi, selamat datang juga Bapak Camat." Bapak menyambut dari atas panggung. (Bagian 7)

Dalam kutipan tersebut, terlihat bahwa tokoh Bapak memberikan salam hormat kepada Bapak Provinsi dan Bapak Camat sebagai bentuk penghormatan terhadap tamu. Diceritakan dalam novel bahwa kutipan tersebut diucapkan tokoh Bapak ketika menyambut pegawai atas yang baru saja tiba di kantor camat, Muara Manowa. Budaya menghormati tamu sangat kental dalam masyarakat, baik di pedesaan maupun di perkotaan. Sebab tamu dianggap sebagai sosok yang telah mengorbankan tenaga, waktu, dan biaya untuk menyempatkan datang. Pengorbanan tersebut sepatutnya kita hargai dengan menunjukkan sikap ramah dan rasa senang hati.

\section{Nilai Agama}

\section{Mendirikan Shalat sebagai Kewajiban terhadap Tuhan}

Kutipan yang menunjukkan adanya sikap memenuhi kewajiban terhadap Tuhan dengan mendirikan shalat, yaitu:

"Baik, kita sudahi untuk malam ini."

Anak-anak bergegas membereskan peralatan mengaji.

"Za."

"Ya, Guru." Sigap aku menjawab.

"Kau yang adzan Isya. Bergegas sana ke masjid, sudah hampir masuk waktunya."

Aku mengangguk. (Bagian 5) 
Dalam kutipan tersebut, terlihat bahwa Guru Rudi memerintahkan Za untuk adzan karena sebentar lagi memasuki waktu Isya. Hal ini mengartikan bahwa warga Kampung Manowa didominasi oleh pemeluk agama islam, dan shalat merupakan kewajiban yang harus dikerjakan. Dalam novel, Guru Rudi diceritakan sebagai guru ngaji di Kampung Manowa. Oleh karena itu, karakter serta kepribadian Guru Rudi digambarkan melekat dengan akhlak-akhlak yang terdapat dalam ajaran islam, salah satunya senantiasa mengingatkan murid laki-lakinya untuk adzan setiap kali waktu shalat wajib tiba.

\section{Mengaji sebagai Amalan}

Kutipan yang menunjukkan adanya kegiatan mengaji yang merupakan amalan seorang muslim, yaitu:

Seperti biasa, habis maghrib kami mengaji di rumah Guru Rudi-tidak jauh dari jembatan menuju mesjid. Yang tidak biasa, setelah anak-anak menyetor bacaan, Ode mendadak mengangkat telunjuknya bertanya. (Bagian 5)

Dalam kutipan tersebut, terlihat bahwa anak-anak Kampung Manowa melakukan kegiatan mengaji setiap selesai shalat maghrib di rumah Guru Rudi. Kegiatan membaca dan menghafal Al-Qur'an merupakan amalan dalam islam. Umumnya dalam lingkungan masyarakat muslim di Indonesia, kegiatan mengaji anak-anak dilakukan di sore hari, selepas ibadah shalat ashar ataupun shalat maghrib. Ternyata, hal tersebut berlaku pula di Kampung Manowa.

\section{Berdoa Sebelum/Setelah Melakukan Kegiatan}

Kutipan yang menunjukkan adanya kegiatan berdoa sebelum/setelah melakukan kegiatan, yaitu:

Wajah Fatah kembali cerah, dia tidak sabaran menunggu centong selesai digunakan Bapak. Langsung meraihnya-padahal itu seharusnya giliran Mamak dulu.

"Oi, kau sudah baca bismillah, Fat? Bapak menegur.

"Shu-dha, Phak." Fatah menjawab dengan mulut penuh nasi. (Bagian 11)

Dalam kutipan tersebut, terlihat bahwa tokoh Bapak menegur sekaligus mengingatkan Fatah untuk tidak melupakan membaca bismillah sebelum makan. Berdoa sebelum makan merupakan bentuk syukur umat islam terhadap rezeki yang telah diberikan Tuhan.

Kutipan di atas adalah contoh adanya nilai agama yang tercermin melalui tindakan berdoa sebelum melakukan kegiatan, adapun berdoa setelah melakukan kegiatan ditunjukkan dalam kutipan berikut ini:

"Rahan, kau pimpin do'a, Nak." Kata Bu Rum beberapa saat kemudian. Kali ini Rahan menurut. Kami memasukkan buku ke dalam tas. Membaca doa bersama, memberi salam pada Bu Rum kemudian berjalan lesu keluar kelas. (Bagian 23)

Dalam kutipan tersebut, terlihat bahwa tokoh Bu Rum memerintahkan Rahan untuk berdoa setelah kegiatan belajar mengajar di hari itu selesai. Berdoa setelah belajar merupakan bentuk syukur dan pengharapan umat islam agar ilmu yang didapat senantiasa dilimpahkan keberkahan.

Terdapat cukup banyak nilai didaktis ataupun nilai pendidikan yang tercermin dalam novel ini. Meskipun pada dasarnya nilai-nilai tersebut saling berhubungan dan memiliki 
keterkaitan yang erat. Misalnya, nilai budaya menghormati tamu dapat pula dikatakan sebagai nilai moral, nilai moral kasih sayang terhadap sesama dapat pula dikatakan sebagai nilai sosial, dan lain sebagainya. Novel Si Anak Badai menyajikan cerita yang erat hubungannya dengan latar belakang kehidupan manusia, adapun latar belakang tersebut meliputi kepercayaan, cara berpikir, nilai-nilai masyarakat, moral, etika, seni, hiburan, dan lain-lain. Selain itu, adanya nilai-nilai didaktis seperti yang telah dijabarkan di atas memungkinkan pembaca termotivasi untuk terus mengembangkan diri serta memperbaiki diri.

\section{Simpulan}

Novel Si Anak Badai karya Tere Liye mengandung nilai-nilai didaktis yang mencakup nilai moral, nilai sosial, nilai budaya, dan nilai agama. Nilai-nilai tersebut dapat diimplementasikan ke dalam kehidupan sehari-hari. Novel ini mengandung begitu banyak amanat serta nilai-nilai kehidupan yang menjadikan pembaca memahami kebermanfaatan dalam menjalani kehidupan. Nilai moral menjadikan seseorang dapat membedakan hal yang baik dan hal yang buruk, nilai sosial menjadikan seseorang mampu berinteraksi dan berkomunikasi dengan lingkungan sekitar, nilai budaya menjadikan seseorang dapat mempertahankan apa yang dinilai baik dalam masyarakat, kemudian nilai agama menjadikan seseorang menyadari kewajiban dan tanggung jawabnya kepada Tuhan.

Dalam penelitian ini, peneliti menemukan nilai moral, di antaranya: membantu orangtua, sikap kasih sayang kepada sesama, meminta maaf saat melakukan kesalahan, mengucapkan terima kasih, bersikap amanah, dan pantang menyerah. Sementara nilai sosial yang ditemukan, di antaranya: tanggung jawab, tolong menolong, gotong royong, kepedulian terhadap sesama, dan musyarah. Kemudian nilai budaya yang ditemukan, di antaranya: mengangkat tangan sebagai permintaan izin bertanya atau menjawab, serta menghormati tamu. Lalu nilai agama yang ditemukan, di antaranya: mendirikan shalat sebagai kewajiban terhadap Tuhan, mengaji sebagai amalan, serta berdoa sebelum dan setelah melakukan kegiatan.

Adapun saran yang perlu diperhatikan bagi peneliti selanjutnya yang tertarik meneliti mengenai nilai-nilai yang terkandung dalam karya sastra diharapkan mencari lebih banyak sumber dan referensi yang relevan, sehingga hasil penelitian dapat lebih lengkap, serta lebih mempersiapkan diri dalam proses pengumpulan data, sehingga penelitian dapat dilakukan dengan sebaik-baiknya.

\section{Daftar Pustaka}

Eriyanto. 2011. Analisis Isi Pengantar Metodologi untuk Penelitian Ilmu Komunikasi dan Ilmu-ilmu Sosial Lainnya. Jakarta: KENCANA.

Haerudin, D. 2012. Mengkaji Nilai-nilai Moral melalui Karya Sastra. Makalah. FPBS: Universitas Pendidikan Indonesia.

Ibung, Dian. 2008. Mengembangkan Nilai Moral pada Anak: Panduan bagi Orang Tua untuk Membimbing Anaknya Menjadi Anak yang Baik. Jakarta: PT Elex Media Komputindo.

Nopitasari. 2020. Nilai-nilai Desa yang Harus Kita Pelihara: Sosial, Moral, Agama. Yogyakarta: CV. HIKAM Media Utama. 
Putro, A. P., Waluyo, H, J., \& Wardhani, N.E. 2020. NILAI-NILAI PENDIDIKAN KARAKTER DALAM NASKAH DRAMA OPERA KECOA KARYA N. RIANTIARNO. Dialektika: Jurnal Bahasa, Sastra, dan Pendidikan Bahasa dan

Raharjo, H. P., dan Eko Wiyanto. 2017. Mengenal Struktur Pembangun Karya Sastra. Sukoharjo: CV Sindunata.

Rahayu, A. P. (2012). Analisis Makna Fukugoudoushi au Dalam Kalimat Bahasa Jepang (Doctoral dissertation, Universitas Pendidikan Indonesia). Sastra Indonesia, $7(1), 1-16$.

Sumaryanto. 2019. Karya Sastra Bentuk Prosa. Semarang: Mutiara Aksara.

Suwardi. 2011. Diktat Sosiologi Sastra. Yogyakarta: FBS Universitas Negeri Yogyakarta. 